\title{
Acupuncture Transmitted Infections
}

\author{
Patrick CY Woo, 1,2,3, Ada WC Lin ${ }^{4}$ and Susanna KP Lau1,2,3,4 \\ ${ }^{1}$ State Key Laboratory of Emerging Infectious Diseases, \\ ${ }^{2}$ Research Centre of Infection and Immunology, \\ ${ }^{3}$ Carol Yu Centre of Infection, \\ ${ }^{4}$ Department of Microbiology, The University of Hong Kong, \\ Hong Kong
}

\section{Introduction}

Among all modalities of alternative medicine, acupuncture is one of the most widely recognized and evidence-based. According to the central concept in Traditional Chinese Medicine, healthy functioning of the various organ systems depends on the body's circulating energy, known as Qi, moving in a harmonious and balanced way through a network of meridians (channels) and collaterals beneath the skin. In this network of meridians, the most important are the 12 main meridians and two of the eight extra meridians, Du Mai and Ren Mai. By inserting and manipulating fine needles into specific acupuncture points that are located in these channels of energy, it can promote the harmonious flow of Qi and stimulate the body's own healing response. By 2010, more than 350 specific acupuncture points have been defined in the World Health Organization classification system. Throughout the years, acupuncture has been widely used for chronic pain, digestive, allergic and menstrual problems as well as cessation of smoking and drug and alcohol rehabilitation.

Involving the insertion of needles up to several centimeters beneath the skin, the practice of acupuncture may pose risks to the recipients. Among all acupuncture associated complications, transmission of pathogenic microorganisms is one of the most important (Woo et al., 2010). With the increasing use of acupuncture globally, infections transmitted by acupuncture have become an emerging health problem. Needle reuse and/or inadequate skin disinfection has led to the transmission of infectious agents, including pyogenic bacteria, mycobacteria and blood borne viruses, from environment-to-patient and patientto-patient. In this article, we reviewed all cases and outbreaks of acupuncture transmitted infections published in the English literature in the past four decades. The importance of setting up and implementation of proper infection control guidelines is also discussed.

\section{Methods}

For initial screening, "acupuncture" was used as the key word for Medline search in the English literature. The results were then manually screened for cases and outbreaks of infections transmitted by acupuncture. All infections transmitted by acupuncture were included. 


\section{Acupuncture transmitted pyogenic bacterial infections}

All reported cases of pyogenic bacterial infections claimed to be associated with acupuncture treatment were sporadic ones, with the exception of one recently reported outbreak (Table). In the past four decades, a total of 52 isolated cases of pyogenic bacterial infections claimed to be associated with acupuncture treatment were reported in the English literature (Baltimore \& Moloy, 1976; Izatt \& Fairman, 1977; Jones \& Cross, 1980; Pierik, 1982; Hadden \& Swanson, 1982; Jefferys et al., 1983; R.J. Lee \& Mcllwain, 1985; Davis \& Powell, 1985; Warwick-Brown \& Richards, 1986; Gillbert, 1987; Scheel et al., 1992; Spleman et al., 1993; Garcia \& Venkataramani, 1994; Kirschenbaum \& Rizzo, 1997; C.Y. Chen et al., 1997; Matsumura et al., 1998; Yazawa et al., 1998; Lau et al., 1998; Ha et al., 1999; Origuchi et al., 2000; Ishibe et al., 2001; Nambiar \& Ratnatunga, 2001; Laing et al., 2002; Uchino et al., 2002; S.Y. Lee \& Chee, 2002; Shah et al., 2002; Woo et al., 2003; Y.P. Cho et al., 2003; Lin \& Choong, 2003; Kettaneh et al., 2003; Daivajna et al., 2004; Saw et al., 2004; M.H. Chen \& Huang, 2004; Studd \& Steward, 2004; Vucicevic et al., 2005; Bang \& Lim, 2006; Simmons, 2006; Seeley \& Chambers, 2006; S. Lee et al., 2008; Tien et al., 2008; Richter et al., 2008; Morgan, 2008; Wu et al., 2009; Woo et al., 2009; Ogasawara et al., 2009; Nakajima et al., 2010; J.W. Kim \& Y.S. Kim, 2010; Macuha et al., 2010; Koo et al., 2010; Chung et al., 2011) (Figure). Thirty-one (60\%) of the cases were reported in the recent 10 years, which is probably related to the increase awareness of this disease entity and reporting of cases. The male to female ratio of the 52 patients was 23 to 29 . The median age was 53 (range 12 - 84). Cases were reported globally from Asia, Europe, America and Australia. In most cases, pyogenic bacteria were transmitted from the patients' skin flora or the environment because of inadequate skin disinfection. Pain and/or stiffness were the reason for acupuncture in $37(80 \%)$ patients, followed by smoking cessation (three patients), weight reduction (three patients), postencephalitic vegetative state (two patients) and dyspepsia (one patient).

\begin{tabular}{|c|c|c|c|c|c|}
\hline References Origin & $\begin{array}{l}\text { No. of Microbes } \\
\text { patients } \\
\text { involved }\end{array}$ & Diagnosis & $\begin{array}{l}\text { Source of } \\
\text { outbreak }\end{array}$ & $\begin{array}{l}\text { Mode of } \\
\text { transmission }\end{array}$ & Outcome \\
\hline
\end{tabular}

Bacterial infections

Murray et Australia al., 2008

Mycobacterial

infections

Ryu et al. Korea

2005; Song

et al., 2006

Tang et al., Canada

2006
8

Methicillin resistant Staphylococcus aureus

Septic Acupuncturist
arthritis and is a nasal
bursitis, carrier of the
pyomyositis same
methicillin
bacteremia
$\begin{array}{ll}\text { resistant } \\ \text { Staphylococcus } \\ \text { aureus }\end{array}$

40

Mycobacteri Cutaneous Not known um abscessus infections

32

Mycobacteri Cutaneous Not known um abscessus infections

Poor infection All survived
control practices
and sterile
techniques e.g.
touch sterile,
gloved hand
with ungloved
hand

Not known Majority with residual skin lesions

Not known All developed residual scarring or hyperpigmenta tion 


\begin{tabular}{|c|c|c|c|c|c|c|}
\hline References Origin & $\begin{array}{c}\text { No. of } \\
\text { patients } \\
\text { involved }\end{array}$ & Microbes & Diagnosis & $\begin{array}{l}\text { Source of } \\
\text { outbreak }\end{array}$ & $\begin{array}{l}\text { Mode of } \\
\text { transmission }\end{array}$ & Outcome \\
\hline $\begin{array}{l}\text { Kim et al., Korea } \\
2010\end{array}$ & 3 & $\begin{array}{l}\text { Mycobacteri } \\
\text { um } \\
\text { tuberculosis }\end{array}$ & $\begin{array}{l}\text { Cutaneous } \\
\text { infections }\end{array}$ & $\begin{array}{l}\text { All patients } \\
\text { received } \\
\text { acupuncture } \\
\text { from an illegal } \\
\text { acupuncturist }\end{array}$ & Not known & $\begin{array}{l}\text { All skin lesions } \\
\text { resolved, one } \\
\text { with residual } \\
\text { mild } \\
\text { hyperpigmenta } \\
\text { tion }\end{array}$ \\
\hline $\begin{array}{l}\text { Koh et al., Korea } \\
2010\end{array}$ & 109 & $\begin{array}{l}\text { Mycobacteri } \\
\text { um abscessus }\end{array}$ & $\begin{array}{l}\text { Cutaneous } \\
\text { infections }\end{array}$ & $\begin{array}{l}\text { Contaminated } \\
\text { disinfectant } \\
\text { (diluted } \\
\text { glutaraldehyde) }\end{array}$ & $\begin{array}{l}\text { Diluted } \\
\text { glutaraldehyde } \\
\text { prepared few } \\
\text { months prior } \\
\text { use } \\
\text { contaminated } \\
\text { physical therapy } \\
\text { devices which } \\
\text { were applied to } \\
\text { patients prior to } \\
\text { acupuncture }\end{array}$ & Unknown \\
\hline
\end{tabular}

\begin{tabular}{|c|c|c|c|c|c|c|c|}
\hline $\begin{array}{l}\text { Boxall, } \\
1978\end{array}$ & UK & 36 & $\begin{array}{l}\text { Hepatitis B } \\
\text { virus }\end{array}$ & $\begin{array}{l}\text { Clinical } \\
\text { hepatitis, } \\
\text { details not } \\
\text { mentioned }\end{array}$ & Not known & \multicolumn{2}{|c|}{$\begin{array}{l}\text { Repetitive use of Not mentioned } \\
\text { unsterilized } \\
\text { needles }\end{array}$} \\
\hline $\begin{array}{l}\text { Stryker et } \\
\text { al., } 1986\end{array}$ & USA & 6 & $\begin{array}{l}\text { Hepatitis B } \\
\text { virus }\end{array}$ & $\begin{array}{l}\text { Icteric } \\
\text { hepatitis }\end{array}$ & $\begin{array}{l}\text { A patient with } \\
\text { hepatitis B } \\
\text { infection }\end{array}$ & $\begin{array}{l}\text { Improperly } \\
\text { sterilized } \\
\text { needles }\end{array}$ & All survived \\
\hline $\begin{array}{l}\text { Slater et } \\
\text { al., } 1988\end{array}$ & Israel & 5 & $\begin{array}{l}\text { Hepatitis B } \\
\text { virus }\end{array}$ & $\begin{array}{l}\text { Clinical } \\
\text { hepatitis, } \\
\text { details not } \\
\text { mentioned }\end{array}$ & $\begin{array}{l}\text { A patient } \\
\text { towards the } \\
\text { end of her } \\
\text { incubation } \\
\text { period }\end{array}$ & $\begin{array}{l}\text { Improperly } \\
\text { sterilized or } \\
\text { unsterilized } \\
\text { needles }\end{array}$ & Not mentioned \\
\hline $\begin{array}{l}\text { Kent et al., } \\
1988\end{array}$ & USA & 35 & $\begin{array}{l}\text { Hepatitis B } \\
\text { virus }\end{array}$ & $\begin{array}{l}\text { Icteric } \\
\text { hepatitis } \\
(\mathrm{n}=11), \\
\text { asymptoma } \\
\text { tic }(\mathrm{n}=24)\end{array}$ & $\begin{array}{l}\text { A patient with } \\
\text { hepatitis B } \\
\text { infection }\end{array}$ & $\begin{array}{l}\text { Repetitive use c } \\
\text { unsterilized } \\
\text { needles or } \\
\text { transfer of } \\
\text { infectious } \\
\text { material to } \\
\text { sterile needles } \\
\text { through the } \\
\text { hands of } \\
\text { acupuncturist }\end{array}$ & $\begin{array}{l}\text { f All survived } \\
\text { and hepatitis B } \\
\text { virus surface } \\
\text { antigen } \\
\text { negative }\end{array}$ \\
\hline $\begin{array}{l}\text { Walsh et } \\
\text { al. } 1999\end{array}$ & UK & 5 & $\begin{array}{l}\text { Hepatitis B } \\
\text { virus }\end{array}$ & $\begin{array}{l}\text { Icteric } \\
\text { hepatitis }\end{array}$ & $\begin{array}{l}\text { Hepatitis B } \\
\text { virus surface } \\
\text { antigen and e } \\
\text { antigen } \\
\text { positive } \\
\text { acupuncturist }\end{array}$ & Not known & Not mentioned \\
\hline
\end{tabular}

Table. Outbreaks of pyogenic bacterial, mycobacterial and viral infections associated with acupuncture 
Clinical diagnosis of pyogenic bacterial infections associated with acupuncture is usually not difficult because of the relatively short incubation period, in terms of days. For localized infections, meridian- and acupuncture point-specific lesions were characteristics, as acupuncture involves insertion of needles into specific acupuncture points at specific locations along the various meridians. Among the 52 sporadic cases, 37 (71\%) patients had musculoskeletal and/or skin infections usually in the form of abscesses or septic arthritis, corresponding to the site of insertion of the acupuncture needles. One case involved use of pharmacopuncture (injection of herbal ingredient which was not produced by sterile standard processes through a thin tube for the purpose of combining effect of acupuncture and the herb) and resulted in multiple abscesses in the psoas region (Koo et al., 2010). In spite of the relatively short incubation period for pyogenic infection associated with acupuncture, the implantation of permanent needles could result in infection occurring years after acupuncture. One case with permanent needles inserted 13 years ago developed prosthetic joint infection two months after total knee arthroplasty, despite sterile synovial fluid and tissue obtained pre-operatively and intra-operatively during primary arthroplasty (Nakajima et al., 2010). It is possible that subclinical infection resulted from the permanent needles in the joint gave rise to prosthetic joint infection after surgical manipulation. Eight (15\%) patients had infective endocarditis and/or mycotic and/or infected atrial myxoma. In most of these cases, the infections were attributed to acupuncture because of a temporal relationship between acupuncture and the infections, of which the incubation period ranged from 2 to 18 days except for one case, and absence of other identified events resulting in transient bacteremia for cardiovascular infections. For the exceptional case, the aortic mycotic aneurysm developed six months after acupuncture, which made the causal relationship less convincing (Origuchi et al., 2000). For the remaining cases, one patient each had meningitis with lumbar epidural hematoma, endophthalmitis complicating cervical spondylitis, retroperitoneal abscess, intraabdominal abscess, empyema thoracis and bacteremia without other primary focus of infection.

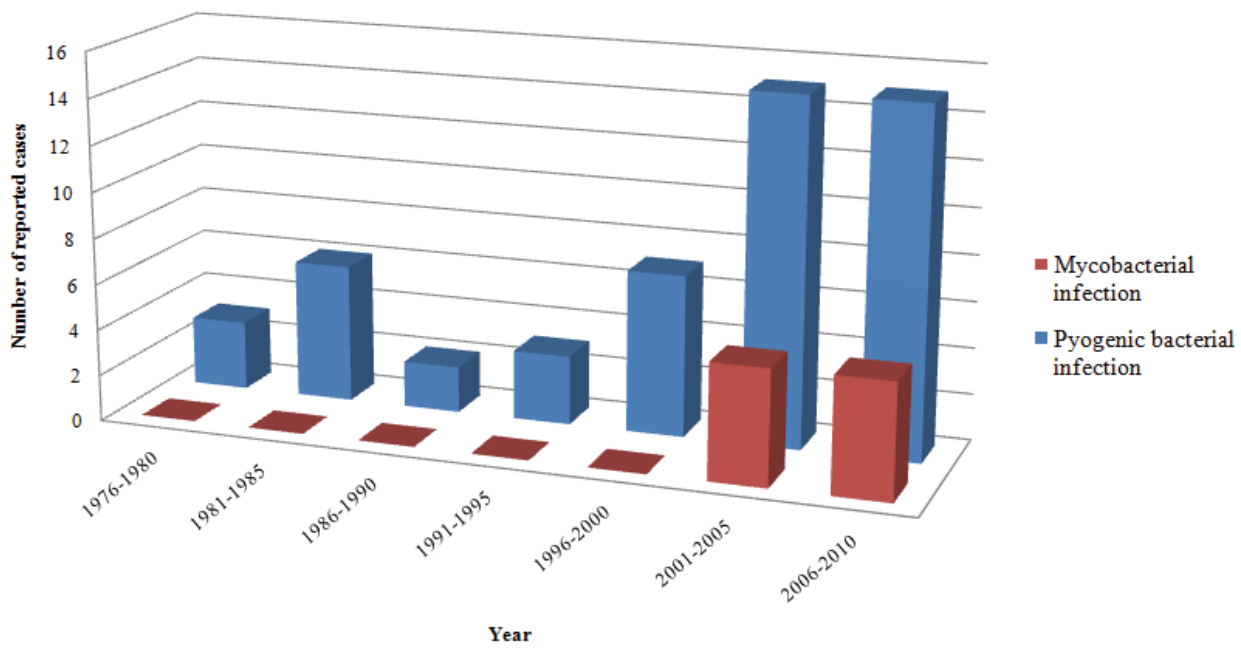

Fig. Sporadic cases of pyogenic bacterial and mycobacterial infections transmitted by acupuncture reported in the English literature 
As in other musculoskeletal and/or skin infections, Staphylococcus aureus is the most common bacterium causing pyogenic infections associated with acupuncture. Among the 41 (79\%) patients with positive cultures in the sporadic cases, $37(90 \%)$ and five $(10 \%)$ had monomicrobial and polymicrobial infections respectively. The most common bacterium recovered was Staphylococcus aureus [22 (54\%) cases], followed by Pseudomonas aeruginosa [five $(12 \%)$ cases], Escherichia coli [three (7\%) cases], Enterococcus faecalis [two (5\%) cases], Bacteroides fragilis [two (5\%) cases] and one case each of Staphylococcus epidermidis, group A streptococcus, group B streptococcus, Streptococcus anginosus, Streptococcus bovis, Listeria monocytogenes, Clostridium botulinum + Clostridium histolyticum + Clostridium subterminale, Bifidobacterium longum, Propionibacterium acnes and Klebsiella pneumoniae. For the patient with infected atrial myxoma associated with Streptococcus bovis, the authors attributed acupuncture to be the cause of infection just because the patient had received repeated courses of acupuncture during a two-month period before the onset of infection, without mentioning the possibility of the gastrointestinal tract as a source of the bacterium (Uchino et al., 2002). Since Streptococcus bovis is not part of the skin flora, this case of Streptococcus bovis infected atrial myxoma associated with acupuncture was not convincing. Nineteen $(37 \%)$ of the patients had positive blood cultures. All of them had monomicrobial bacteremia, with Staphylococcus aureus being the most common bacterium recovered [11 (58\%) cases], followed by one case each of group A streptococcus, group B streptococcus, Streptococcus bovis, Bifidobacterium longum, Propionibacterium acnes, Pseudomonas aeruginosa, Escherichia coli and Klebsiella pneumoniae.

Pyogenic bacterial infections associated with acupuncture had resulted in major morbidity and mortality with long duration of antibiotics and hospital stay. Standard antibiotics with or without surgical intervention were the mainstay of treatment for pyogenic bacterial infections associated with acupuncture. Among the $35(67 \%)$ patients in the sporadic cases with duration of antibiotics reported, four $(11 \%)$, six $(17 \%)$ and $18(51 \%)$ received 2 to $<4$ weeks, 4 to $<6$ weeks and $\geq 6$ weeks of antibiotics respectively. Thirty-five $(67 \%)$ patients required drainage and/or other surgical treatment. Overall, three (6\%) patients died. Although most infections started with localized infections and almost all patients were immunocompetent, a significant proportion had resulted in serious consequences, such as joint destruction, paraplegia, necrotizing fasciitis and multiorgan failure.

In addition to the 52 isolated cases, one outbreak of methicillin resistant Staphylococcus aureus infections associated with acupuncture, which represented the first reported outbreak of pyogenic infections associated with acupuncture, was described recently from Australia (Table) (Murray et al., 2008). Five of the patients had septic arthritis and bursitis and the other three had pyomyositis. Three patients had bacteremia. The source of the outbreak was traced to an acupuncturist, who carried the same methicillin resistant Staphylococcus aureus as the patients in his nasal cavity, demonstrated by pulsed field gel electrophoresis and ribotying. All patients responded to prolonged antibiotics treatment (median 72 days, range 21 - 127 days) and none of the patients died.

\section{Acupuncture transmitted mycobacterial infections}

In contrast to pyogenic bacterial infections, only eleven sporadic cases of acupunctureassociated mycobacteriosis have been reported in the English literature (Woo et al., 2001, 2002; Ara et al., 2003; H.J. Cho et al., 2010; W.J. Lee et al., 2010; Guevara-Patiño et al., 2010; Castro-Silva et al., 2011) (Figure). On the other hand, four outbreaks have been described 
(Table) (Ryu et al., 2005; Song et al., 2006; Tang et al., 2006; J.K. Kim et al., 2010; Koh et al., 2010). While one outbreak involved 32 patients from Canada, the other three were all reported from Korea including the largest outbreak involving up to 109 patients (Koh et al., 2010). One of them, involving 40 patients, was reported by two groups from Korea (Ryu et al., 2005; Song et al., 2006), whereas the other one involved only three patients (J.K. Kim et al., 2010). Although only rarely documented by positive culture of environmental samples, mycobacteria were believed to be transmitted from the environment to the patients via contaminated equipments used for acupuncture treatment in most cases, such as cotton wool swabs, towels, hot pack covers and boiling tank. In the largest outbreak reported from Korea (Koh et al., 2010), Mycobacterium abscessus was isolated from the contaminated disinfectant (diluted glutaraldehyde) which was believed to be the source of outbreak. During the disinfection process, the electrodes for interferential current and low-frequency therapies may have been contaminated and mycobacteria were transmitted to the skin of the patients during physical therapy. The subsequent needle penetration then introduced the infection.

All mycobacterial infections associated with acupuncture were characterized by localized meridian- and acupuncture point-specific lesions without dissemination. In the Canadian outbreak involving 32 patients, all lesions developed over previous acupuncture sites, and about one third of the patients had 10 or more lesions (Tang et al., 2006). Usually the lesions first appeared as erythematous papules and nodules that subsequently developed into large pain pustules, abscesses and ulcerative lesions after several weeks to months (Woo et al., 2001, 2002; Ara et al., 2003; H.J. Cho et al., 2010; W.J. Lee et al., 2010; Guevara-Patiño, et al., 2010; Castro-Silva et al., 2011; Ryu et al., 2005; Song et al., 2006; Tang et al., 2006). Among all the reported cases, only around $10 \%$ of them had systemic symptoms (Koh et al., 2010).

In contrast to pyogenic bacterial infections, acupuncture-associated mycobacteriosis were often associated with delay in diagnosis. Acupuncture-associated mycobacteriosis were associated with a relatively long incubation period. In the Korean and Canadian outbreaks that involved a total of 184 patients, the median incubation periods ranged from one week to 4.75 weeks (Ryu et al., 2005; Song et al., 2006; Tang et al., 2006; J.K. Kim et al., 2010; Koh et al., 2010). This is in line with the long incubation periods of one to three months in infections due to rapidly growing mycobacteria, as reported in cases of Mycobacterium chelonae and/or Mycobacterium fortuitum infections of breast implants, midpalmar space, epidural space, and skin (Safranek et al., 1987; O'Brien \& Rawluk, 1999; Clegg et al., 1983; Camargo et al., 1996; Crick \& Vandevelde, 1986). The long incubation period rendered patients unable to associate the event of acupuncture with the clinical illness. Moreover, patients tended to delay in seeking medical advice because of the indolent and relatively mild symptoms. In the Canadian outbreak, some patients continued to receive acupuncture treatments while they had lesions on their bodies (Tang et al., 2006). Furthermore, failure of the attending clinicians to recognize acupuncture-associated mycobacteriosis as a cause of indolent skin and soft tissue infection due to a lack of awareness of such a disease entity, as well as the assumption of "adequate" skin disinfection with alcohol and the use of disposable acupuncture needles, have also resulted in delay in diagnosis. In the four sporadic cases of mycobacterial infections associated with acupuncture reported earlier in the year 2001 and 2002, the diagnosis was made during subsequent infectious disease consultations, when the patients recalled the history of acupuncture only on direct questioning of whether the involved site has been penetrated by sharp objects in recent months (Woo et al., 2001, 2002). 
In the two outbreaks reported in the mid-2000s, the median time to correct diagnosis was about three to four months (Ryu et al., 2005; Song et al., 2006; Tang et al., 2006). Of note is that the first case of acupuncture transmitted mycobacterial infection was reported in 2001 (Woo et al., 2001), 25 years after the first case of acupuncture transmitted pyogenic bacterial infection was described!

The reported cases of acupuncture mycobacteriosis were caused by both rapidly and slow growing mycobacteria, as recovered in biopsy specimens of the lesions, which responded to the anti-mycobacterial treatment for the corresponding mycobacteria with or without surgical excision. In the three large outbreaks, Mycobacterium abscessus was the causative microbe isolated (Ryu et al., 2005; Song et al., 2006; Tang et al., 2006; Koh et al., 2010), whereas in the sporadic cases, a wider variety of mycobacteria were recovered, including Mycobacterium chelonae, Mycobacterium nonchromogenicum, Mycobacterium abscessus, Mycobacterium avium complex and Mycobacterium haemophilum (Woo et al., 2001, 2002; Ara et al., 2003; H.J. Cho et al., 2010; W.J. Lee et al., 2010; Guevara-Patiño et al., 2010; Castro-Silva et al., 2011). In addition to the conventional laboratory methods, $16 \mathrm{~S}$ ribosomal RNA gene sequencing and/or sequencing other housekeeping genes were important for identification of the Mycobacterium species responsible for causing the infections (Woo et al., 2008). Despite generally not environmental in origin, Mycobacterium tuberculosis was identified as the causative microbe in one outbreak involving three patients who developed cutaneous infection corresponding to the acupunctural sites (Kim et al., 2010). The diagnosis was confirmed by polymerase chain reaction in two patients with one of them also being cultured positive. Histologically, all cases were characterized by typical features of mycobacterial infections, such as granulomatous inflammation, caseous necrosis and epithelioid and multinucleated giant cells with or without the presence of acid fast bacilli (Woo et al., 2001, 2002; Ara et al., 2003; H.J. Cho et al., 2010). For medical treatment against the rapid growers, we recommended a combination of imipenem, clarithromycin/azithromycin and amikacin in the first few weeks for a rapid reduction of mycobacterial load and reducing the chance of emergence of resistance, followed by clarithromycin/azithromycin maintenance for a few more months. Surgical excision would be necessary for large lesions. Although most patients responded, a lot of the patients had residual scarring and/or hyperpigmentation.

\section{Acupuncture transmitted viral infections}

Theoretically, all blood borne viruses can be potentially transmitted by acupuncture. In the literature, the best documented cases were hepatitis B virus, and to a less extent, hepatitis C virus. Most cases of acupuncture associated blood borne virus infections were due to transmission of the virus from one acupuncture patient who carried the virus to another. Occasionally, the infection was transmitted from the acupuncturist who carried the virus to the patient. In all these cases, reusable acupuncture needles that were inadequately sterilized were used. As a result of the increasing use of disposable needles, the incidence of blood borne viruses transmitted by acupuncture will be expected to decrease.

\subsection{Hepatitis $B$ virus}

Among the blood borne viruses transmitted by acupuncture, hepatitis B virus is the best documented one, and is also the one involved in the largest number of outbreaks globally, 
which have provided invaluable information on the epidemiology of acupuncture transmitted hepatitis B virus infections. A total of five acupuncture transmitted hepatitis B virus outbreaks have been reported in the English literature, involving more than 80 patients (Table) (Boxall, 1978; Stryker et al., 1986; Slater et al., 1988; Kent et al., 1988; Walsh et al., 1999). In most of the outbreaks, the sources were patients with hepatitis B virus infections. Hepatitis B virus was transmitted from one patient to another through improperly sterilized or unsterilized reusable acupuncture needles. In one of the outbreaks, a hepatitis B virus surface antigen and hepatitis B virus e antigen positive acupuncturist was believed to be the source, although the acupuncturist denied testing the sharpness of needles on his own skin before inserting them into patients.

\subsection{Hepatitis $C$ virus}

Unlike hepatitis B virus, hepatitis C virus infections are almost always asymptomatic in the acute phase. Therefore, it is difficult to ascertain that acupuncture as the definite route of transmission of the virus by tracing the source and performing molecular typing studies. Moreover, outbreaks, if occurred, would be difficult to recognize, and therefore none have been reported in the literature. On the other hand, most evidence for the association of hepatitis $C$ virus infection with acupuncture came from epidemiological and case control studies. In more than 10 of these studies carried out in different parts of the world, acupuncture was found to be an independent risk factor for hepatitis $C$ virus infections (Karmochkine et al., 2006; Kweon et al., 2006; Karaca et al., 2006; Lasher et al., 2005; Ernst \& Sherman, 2003; Shin et al., 2000, 2002; Sanchez et al., 2000; Sun et al., 1999; Balasekaran et al., 1999; Kayaba et al., 1998; Sulaiman et al., 1995; Kiyosawa et al., 1994; Cavalheiro Nde et al., 2009).

\subsection{Human immunodeficiency virus}

Unlike hepatitis B virus transmitted by acupuncture with concrete evidence of outbreaks and molecular typing that confirmed the same hepatitis B virus strain from the source and recipients and hepatitis $C$ virus transmitted by acupuncture with evidence from case-control studies, the evidence of human immunodeficiency virus transmitted by acupuncture was just circumstantial. In all the five cases of "acupuncture associated human immunodeficiency virus infections" reported in the English literature, the human immunodeficiency virus positive patients had no other risk factors for the human immunodeficiency virus infection, such as transfusion, sexual intercourse, haemophilia, intravenous drug use or other injections, operation, and tattooing, other than acupuncture (Chamberland et al., 1989; Vittecoq et al., 1989; Castro et al., 1988; Wiwanitkit, 2003).

\section{Infection control in acupuncture}

To prevent acupuncture transmitted infections, strict adherence to proper infection control guidelines is mandatory. Although guidelines for carrying out the proper procedures of acupuncture are available (Chinese Medicine Registration Board of Victoria), implementation of such guidelines, even in developed countries, is far from ideal. To prevent transmission of microbes from acupuncturists to patients, acupuncturists should be vaccinated against hepatitis B virus and they should not test the sharpness of needles on their own skin before inserting them into patients. To prevent patient-to-patient 
transmission of blood borne viruses, the use of disposable acupuncture needles should be strictly followed. Needle reuse should be discouraged because almost all hepatitis B virus outbreaks, and probably other undocumented cases of patient-to-patient transmission of blood borne viruses, were transmitted by improperly sterilized reuse needles. In a recent survey, it was found that in village clinics in mainland China, reusable acupuncture needles were disinfected with alcohol rather than being sterilized, due to concerns that sterilization might blunt the needles (Reynolds \& McKee, 2008). Furthermore, proper disinfection of work area (Chinese Medicine Registration Board of Victoria) and physical device, as well as good personal hygiene and proper skin disinfection before needle insertion is the cornerstone to prevent environment-to-patient transmission of pyogenic and mycobacterial infections. Medicinal herbs or agents used for pharmacopuncture treatment must be produced and controlled by sterilization or standardization. Among the infectious agents transmitted by acupuncture, mycobacteria survive the best in disinfectants. As mycobacteria are resistant to chlorhexidine, we recommend that the acupuncturist should wash his/her hands with alcoholic chlorhexidine or povidone iodine before acupuncture treatment. Surgical masks should be worn during needle insertion. The patient's skin should be disinfected by swabbing with $75 \%$ alcohol that is properly reconstituted without top up. While there was inadequate evidence to support a "minimum disinfection time", the Australian Acupuncture Association Infection Control Guidelines for Acupuncture recommended that the skin disinfection time should be at least 30 seconds or the site of insertion should be "just dry" before the patient's skin is pierced (Australian Acupuncture Association Limited, 1997). However, our results showed that mycobacteria can survive in alcohol for up to 45 seconds (Woo et al., 2002). Therefore, skin disinfection time of at least one minute is recommended before insertion of acupuncture needle. To ensure adequate time for disinfection, the acupuncturist can disinfect a group of acupuncture sites before inserting the needles in a sequential order.

\section{Conclusion}

In the 1970s and 1980s, the majority of the infections associated with acupuncture were sporadic cases of pyogenic bacterial infections, mainly due to Staphylococcus aureus, as well as outbreaks of hepatitis B virus infections. As a result of the increasing use of disposable needles in developed in countries, the reported incidence of blood borne viruses transmitted by acupuncture has decreased in 1990s, while acupuncture-transmitted pyogenic bacterial infections persisted. In 2000s, a novel clinical syndrome, acupuncture mycobacteriosis, mainly caused by rapidly growing mycobacteria, has emerged. Due to the relatively hardy nature of mycobacteria, the long incubation period and difficulty in making diagnosis, mycobacteria has caused acupuncture associated outbreaks involving large numbers of patients. The case reports and outbreaks on acupuncture-transmitted infections we summarized in this article are just the tip of the iceberg of a global emerging problem. Although China is presumably the country where acupuncture is most widely used and the hygienic conditions in mainland China are far from ideal with the use of reusable acupuncture needles still in practice, none of the reports of sporadic cases or outbreaks were from mainland China. In 2009, there were first reports of methicillin resistant Staphylococcus aureus transmitted by acupuncture. We predict that the emergence of community-associated methicillin resistant Staphylococcus aureus infections would further aggravate the problem. To prevent acupuncture-transmitted infections, more resources should be spent on 
implementation of proper infection control guidelines, as the financial burden due to prolonged hospitalization and antimicrobial and surgical treatment, the long-term sequel and mortality would be far beyond that used for implementation of guidelines.

\section{References}

Ara, M., de Santamaría, C.S., Zaballos, P., Yus, C., \& Lezcano, M.A. (2003). Mycobacterium chelonae infection with multiple cutaneous lesions after treatment with acupuncture. Int J Dermatol, Vol.42, No. pp.8, pp. 642-644, ISSN 0011-9059

Australian Acupuncture Association Limited. Infection control guidelines for acupuncture, 1st ed. 1997. Australian Acupuncture and Chinese Medicine Association Ltd., Queensland, Australia

Balasekaran, R., Bulterys, M., Jamal, M.M., Quinn, P.G., Johnston, D.E., Skipper, B., Chaturvedi, S., \& Arora, S. (1999). A case-control study of risk factors for sporadic hepatitis C virus infection in the southwestern United States. Am J Gastroenterol, Vol.94, No.5, pp. 1341-1346, ISSN 0002-9270

Baltimore, R.S., \& Moloy, P.J. (1976). Perichondritis of the ear as a complication of acupuncture. Arch Otolaryngol, Vol.102, No.9, pp. 572-573, ISSN 0003-9977

Bang, M.S., \& Lim, S.H. (2006). Paraplegia caused by spinal infection after acupuncture. Spinal Cord, Vol.44, No.4, pp. 258-259, ISSN 1362-4393

Boxall, E.H. (1978). Acupuncture hepatitis in the West Midlands, 1977. J Med Virol, Vol.2, No.4, pp. 377-379, ISSN 0146-6615

Camargo, D., Saad, C., Ruiz, F., Ramirez, M.E., Lineros, M., Rodriguez, G., Navarro, E., Pulido, B., \& Orozco, L.C. (1996). Iatrogenic outbreak of M. chelonae skin abscesses. Epidemiol Infect, Vol.117, No.1, pp. 113-119, ISSN 0950-2688

Castro, K.G., Lifson, A.R., \& White, C.R. (1988). Investigations of AIDS patients with no previously identified risk factors. JAMA, Vol.259, No.9, pp. 1338-1342, ISSN 00987484

Castro-Silva, A.N., Freire, A.O., Grinbaum, R.S., Elmor de Araújo, M.R., Abensur, H., Araújo, M.R., Romão, J.E. Jr, Sampaio, J.L., \& Noronha, I.L. (2011). Cutaneous Mycobacterium haemophilum infection in a kidney transplant recipient after acupuncture treatment. Transpl Infect Dis, Vol.13, No.1, pp. 33-37, ISSN 1398-2273

Cavalheiro Nde, P., De La Rosa, A., Elagin, S., Tengan, F.M., Araújo, E.S., \& Barone, A.A. (2009). Hepatitis C: sexual or intrafamilial transmission? Epidemiological and phylogenetic analysis of hepatitis C virus in 24 infected couples. Rev Soc Bras Med Trop, Vol.42, No.3, pp. 239-244, ISSN 0037-8682

Chamberland, M.E., Conley, L.J., \& Buehler, J.W. (1989). Unusual modes of HIV transmission. N Engl J Med, Vol.321, No.21, pp. 1476-1477, ISSN 0028-4793

Chen, C.Y., Liu, G.C., Sheu, R.S., \& Huang, C.L. (1997). Bacterial meningitis and lumbar epidural hematoma due to lumbar acupunctures: a case report. Kaohsiung J Med Sci, Vol.13, No.5, pp. 328-331, ISSN 1607-551X

Chen, M.H., \& Huang, J.S. (2004). Cervical subdural empyema following acupuncture. J Clin Neurosci, Vol.11, No.8, pp. 909-911, ISSN 0967-5868

Chinese Medicine Registration Board of Victoria. Guidelines on Infection Prevention and Control for Acupuncturists.

http://www.cmrb.vic.gov.au/information/p\&c/practiceconduct/gipca.html 
Cho, H.J., Lee, D.Y., Lee, J.H., Yang, J.M., \& Lee, E.S. (2010). A case of Mycobacterium abscessus skin infection caused by multiple acupunctures. Clin Exp Dermatol, Vol.35, No.4. pp. 444-445, ISSN 0307-6938

Cho, Y.P., Jang, H.J., Kim, J.S., Kim, Y.H., Han, M.S., \& Lee, S.G. (2003). Retroperitoneal abscess complicated by acupuncture: case report. J Korean Med Sci, Vo.18, No.5, pp. 756-757, ISSN 1011-8934

Chung, S.D., Chang, C.H., Wu, K., \& Chu, S.H. (2011). Post-acupuncture shoulder swelling. QJM, 2011 Jan 27 [Epub ahead of print], ISSN 1460-2725

Clegg, H.W., Foster, M.T., Sanders, W.E. Jr, \& Baine, W.B. (1983). Infection due to organisms of the Mycobacterium fortuitum complex after augmentation mammaplasty: clinical and epidemiologic features. J Infect Dis, Vol.147, No.3, pp. 427-433, ISSN 0022-1899

Crick, J.C., \& Vandevelde, A.G. (1986). Mycobacterium fortuitum midpalmar space abscess: a case report. J Hand Surg Am, Vol.11, No.3, pp. 438-440, ISSN 0363-5023

Daivajna, S., Jones, A., O'Malley, M., \& Mehdian, H. (2004). Unilateral septic arthritis of a lumbar facet joint secondary to acupuncture treatment--a case report. Acupunct Med, Vol.22, No.3, pp. 152-155, ISSN 0964-5284

Davis, O., \& Powell, W. (1985). Auricular perichondritis secondary to acupuncture. Arch Otolaryngol, Vol.111, No.11, pp. 770-771, ISSN 0003-9977

Ernst, E., \& Sherman, K.J. (2003). Is acupuncture a risk factor for hepatitis? Systematic review of epidemiological studies. J Gastroenterol Hepatol, Vol.18, No.11, pp. 12311236, ISSN 0815-9319

Garcia, A.A., \& Venkataramani, A. (1994). Bilateral psoas abscesses following acupuncture. West J Med, Vol.161, No.1, pp. 90, ISSN 0093-0415

Gillbert, J.G. (1987). Auricular complication of acupuncture. N Z Med J, Vol.100, No.819, pp. 141-142, ISSN 0028-8446

Guevara-Patiño, A., Sandoval de Mora, M., Farreras, A., Rivera-Olivero, I., Fermin, D., \& de Waard, J.H. (2010). Soft tissue infection due to Mycobacterium fortuitum following acupuncture: a case report and review of the literature. J Infect Dev Ctries, Vol.4, No.8, pp. 521-525, ISSN 2036-6590

Ha, G.Y., Yang, C.H., Kim, H., \& Chong, Y. (1999). Case of sepsis caused by Bifidobacterium longum. J Clin Microbiol, Vol.37, No.4, pp. 1227-1228, ISSN 0095-1137

Hadden, W.A., \& Swanson, A.J. (1982). Spinal infection caused by acupuncture mimicking a prolapsed intervertebral disc. A case report. J Bone Joint Surg Am, Vol.64, No.4, pp. 624-626, ISSN 0021-9355

Ishibe, M., Inoue, M., \& Saitou, K. (2001). Septic arthritis of a lumbar facet joint due to pyonex. Arch Orthop Trauma Surg, Vol.121, No.1-2, pp. 90-92, ISSN 0936-8051

Izatt, E., \& Fairman, M. (1977). Staphylococcal septicaemia with disseminated intravascular coagulation associated with acupuncture. Postgrad Med J, Vol.53, No.619, pp. 285286, ISSN 0032-5473

Jefferys, D.B., Smith, S., Brennad-Roper, D.A., \& Curry, P.V. (1983). Acupuncture needles as a cause of bacterial endocarditis. Br Med J (Clin Res Ed.), Vol.287, No.6388, pp. 326327, ISSN 0267-0623

Jones, R.O., \& Cross, G. (1980). Suspected chronic osteomyelitis secondary to acupuncture treatment: a case report. J Am Podiatry Assoc, Vol.70, No.3, pp. 149-151, ISSN 00030538 
Karaca, C., Cakaloğlu, Y., Demir, K., Ozdil, S., Kaymakoğlu, S., Badur, S., \& Okten, A. (2006). Risk factors for the transmission of hepatitis $C$ virus infection in the Turkish population. Dig Dis Sci, Vol.51, No.2, pp. 365-369, ISSN 0163-2116

Karmochkine, M., Carrat, F., Dos Santos, O., Cacoub, P., \& Raguin, G. (2006). A case-control study of risk factors for hepatitis $C$ infection in patients with unexplained routes of infection. J Viral Hepat, Vol.13, No.11, pp. 775-782, ISSN 1352-0504

Kayaba, K., Igarashi, M., Okamoto, H., \& Tsuda, F. (1998). Prevalence of anti-hepatitis C antibodies in a rural community without high mortality from liver disease in Niigata prefecture. J Epidemiol, Vol.8, No.4, pp. 250-255, ISSN 0917-5040

Kent, G.P., Brondum, J., Keenlyside, R.A., LaFazia, L.M., \& Scott, H.D. (1988). A large outbreak of acupuncture-associated hepatitis B. Am J Epidemiol, Vol.127, No.3, pp. 591-598, ISSN 0002-9262

Kettaneh, A., Ozan, N., Stirnemann, J., Fain, O., \& Thomas, M. (2003). Facial erysipelas after receiving acupuncture treatment. Scand J Infect Dis, Vol.35, No.11-12, pp. 911-912, ISSN 0036-5548

Kim, J.K., Kim, T.Y., Kim, D.H., \& Yoon, M.S. (2010). Three cases of primary inoculation tuberculosis as a result of illegal acupuncture. Ann Dermatol, Vol.22, No.3, pp. 341345, ISSN 1013-9087

Kim, J.W., \& Kim, Y.S. (2010). Psoas abscess formation after acupuncture in a hemodialysis patient. Hemodial Int, Vol.14, No.3, pp. 343-344, ISSN 1492-7535

Kirschenbaum, A.E., \& Rizzo, C. (1997). Glenohumeral pyarthrosis following acupuncture treatment. Orthopedics, Vol.20, No.12, pp. 1184-1186, ISSN 0147-7447

Kiyosawa, K., Tanaka, E., Sodeyama, T., Yoshizawa, K., Yabu, K., Furuta, K., Imai, H., Nakano, Y., Usuda, S., Uemura, K., et al. (1994). Transmission of hepatitis C in an isolated area in Japan: community-acquired infection. The South Kiso Hepatitis Study Group. Gastroenterology, Vol.106, No.6, pp. 1596-1602, ISSN 0016-5085

Koh, S.J., Song, T., Kang, Y.A., Choi, J.W., Chang, K.J., Chu, C.S., Jeong, J.G., Lee, J.Y., Song, M.K., Sung, H.Y., Kang, Y.H., \& Yim, J.J. (2010). An outbreak of skin and soft tissue infection caused by Mycobacterium abscessus following acupuncture. Clin Microbiol Infect, Vol.16, No.7, pp. 895-901, ISSN 1198-743X

Koo, E.H., Choi, S.S., Chung, D.H., Lee, I.O., Kim, N.S., \& Lim, S.H. (2010). Multiple psoas abscess formation after pharmacopuncture -a case report-. Korean J Pain, Vol.23, No.4, pp. 270-273, ISSN 2005-9159

Kweon, S.S., Shin, M.H., Song, H.J., Jeon, D.Y., \& Choi, J.S. (2006). Seroprevalence and risk factors for hepatitis $\mathrm{C}$ virus infection among female commercial sex workers in South Korea who are not intravenous drug users. Am J Trop Med Hyg, Vol.74, No.6, pp. 1117-1121, ISSN 0002-9637

Laing, A.J., Mullett, H., \& Gilmore, M.F. (2002). Acupuncture-associated arthritis in a joint with an orthopaedic implant. J Infect, Vol.44, No.1, pp. 43-44, ISSN 0163-4453

Lasher, L.E., Elm, J.L., Hoang, Q., Nekomoto, T.S., Cashman, T.M., Miller, F.D., \& Effler, P.V. (2005). A case control investigation of hepatitis C risk factors in Hawaii. Hawaii Med J, Vol.64, No.11, pp. 296-304, ISSN 0017-8594

Lau, S.M., Chou, C.T., \& Huang, C.M. (1998). Unilateral sacroiliitis as an unusual complication of acupuncture. Clin Rheumatol, Vol.17, No.4, pp. 357-358, ISSN 07703198 
Lee, R.J., \& McIlwain, J.C. (1985). Subacute bacterial endocarditis following ear acupuncture. Int J Cardiol, Vol.7, No.1, pp. 62-63, ISSN 0167-5273

Lee, S., Lim, S.H., Kim, D.K., \& Joo, H.C. (2008). Acupuncture induced necrotizing aortitis with infected pseudoaneurysm formation. Yonsei Med J, Vol.49, No.2, pp. 322-324, ISSN 0513-5796

Lee, S.Y., \& Chee, S.P. (2002). Group B streptococcus endogenous endophthalmitis: case reports and review of the literature. Ophthalmology, Vol.109, No.10, pp. 1879-1886, ISSN 0161-6420

Lee, W.J., Kang, S.M., Sung, H., Won, C.H., Chang, S.E., Lee, M.W., Kim, M.N., Choi, J.H., \& Moon, K.C. (2010). Non-tuberculous mycobacterial infections of the skin: a retrospective study of 29 cases. J Dermatol, Vol.37, No.11, pp. 965-972, ISSN 03852407

Lin, F., \& Choong, P. (2003). Soft tissue abscess and osteomyelitis secondary to acupuncture. ANZ J Surg, Vol.73, No.9, pp. 770, ISSN 1445-1433

Macuha, F. Jr, Ahn, A., \& Graham, R. (2010). Necrotizing fasciitis associated with acupuncture: a case report. J Hosp Med, Vol.5, No.9, pp. 565-566, ISSN 1553-5592

Matsumura, Y., Inui, M., \& Tagawa, T. (1998). Peritemporomandibular abscess as a complication of acupuncture: a case report. J Oral Maxillofac Surg, Vol.56, No.4, pp. 495-496, ISSN 0278-2391

Morgan, A.E. (2008). Pseudomonas aeruginosa infection due to acupunctural ear stapling. Am J Infect Control, Vol.36, No.8, pp. 602, ISSN 0196-6553

Murray, R.J., Pearson, J.C., Coombs, G.W., Flexman, J.P., Golledge, C.L., Speers, D.J., Dyer, J.R., McLellan, D.G., Reilly, M., Bell, J.M., Bowen, S.F., \& Christiansen, K.J. (2008). Outbreak of invasive methicillin-resistant Staphylococcus aureus infection associated with acupuncture and joint injection. Infect Control Hosp Epidemiol, Vol.29, No.9, pp. 859-865, ISSN 0899-823X

Nakajima, A., Kaneyama, R., Watanabe, H., Murakami, M., Nakagawa. K., Aoki, Y., Yamazaki, M., Furufu, T., \& Suguro, T. (2010). Acupuncture needle-associated prosthetic knee infection after total knee arthroplasty. Mod Rheumatol, Vol.20, No.6, pp. 627-631, ISSN 1439-7595

Nambiar, P., \& Ratnatunga, C. (2001). Prosthetic valve endocarditis in a patient with Marfan's syndrome following acupuncture. J Heart Valve Dis, Vol.10, No.5, pp. 689690, ISSN 0966-8519

O'Brien, D.P., \& Rawluk, D.J. (1999). Iatrogenic mycobacterium infection after an epidural injection. Spine, Vol.24, No.12, pp. 1257-1259, ISSN 0362-2436

Ogasawara, M., Oda, K., Yamaji, K., \& Takasaki, Y. (2009). Polyarticular septic arthritis with bilateral psoas abscesses following acupuncture. Acupunct Med, Vol.27, No.2, pp. 81-82, ISSN 0964-5284

Origuchi, N., Komiyama, T., Ohyama, K., Wakabayashi, T., \& Shigematsu, H. (2000). Infectious aneurysm formation after depot acupuncture. Eur J Vasc Endovasc Surg, Vol.20, No.2, pp. 211-213, ISSN 1078-5884

Pierik, M.G. (1982). Fatal staphylococcal septicemia following acupuncture: report of two cases. Occurrence of staphylococcal septicemia following acupuncture emphasizes need for thorough medical evaluation before such procedures. R I Med J, Vol.65, No.6, pp. 251-253, ISSN 0363-7913 
Reynolds, L., \& McKee, M. (2008). Possible risks of transmission of bloodborne infection via acupuncture needles in Guizhou province, southwest China. J Altern Complement Med, Vol.14, No.10, pp. 1281-1285, ISSN 1075-5535

Richter, J.C., Kamali, W., \& O'Connor, P. (2008). Pneumothorax and pleural empyema after acupuncture. Intern Med J, Vol.38, No.8, pp. 678-680, ISSN 1444-0903

Ryu, H.J., Kim, W.J., Oh, C.H., \& Song, H.J. (2005). Iatrogenic Mycobacterium abscessus infection associated with acupuncture: clinical manifestations and its treatment. Int J Dermatol, Vol.44, No.10, pp. 846-850, ISSN 0011-9059

Safranek, T.J., Jarvis, W.R., Carson, L.A., Cusick, L.B., Bland, L.A., Swenson, J.M., \& Silcox V.A. (1987). Mycobacterium chelonae wound infections after plastic surgery employing contaminated gentian violet skin-marking solution. $N$ Engl J Med, Vol.317, No.4, pp. 197-201, ISSN 0028-4793

Sanchez, J.L., Sjogren, M.H., Callahan, J.D., Watts, D.M., Lucas, C., Abdel-Hamid, M., Constantine, N.T., Hyams, K.C., Hinostroza, S., Figueroa-Barrios, R., \& Cuthie, J.C. (2000). Hepatitis C in Peru: risk factors for infection, potential iatrogenic transmission, and genotype distribution. Am J Trop Med Hyg, Vol.63, No.5-6, pp. 242-248, ISSN 0002-9637

Saw, A., Kwan, M.K., \& Sengupta, S. (2004). Necrotising fasciitis: a life-threatening complication of acupuncture in a patient with diabetes mellitus. Singapore Med J, Vol.45, No.4, pp. 180-182, ISSN 0037-5675

Scheel, O., Sundsfjord, A., Lunde, P., \& Andersen, B.M. (1992). Endocarditis after acupuncture and injection--treatment by a natural healer. JAMA, Vol.267, No.1, pp. 56, ISSN 0098-7484

Seeley, E.J., \& Chambers, H.F. (2006). Diabetic ketoacidosis precipitated by Staphylococcus aureus abscess and bacteremia due to acupuncture: case report and review of the literature. Clin Infect Dis, Vol.43, No.1, pp. e6-e8, ISSN 1058-4838

Shah, N., Hing, C., Tucker, K., \& Crawford, R. (2002). Infected compartment syndrome after acupuncture. Acupunct Med, Vol.20, No.2-3, pp. 105-106, ISSN 0964-5284

Shin, H.R., Kim, J.Y., Ohno, T., Cao, K., Mizokami, M., Risch, H., \& Kim, S.R. (2000). Prevalence and risk factors of hepatitis $C$ virus infection among Koreans in rural area of Korea. Hepatol Res, Vol.17, No.3, pp. 185-196, ISSN 1386-6346

Shin, H.R., Kim, J.Y., Kim, J.I., Lee, D.H., Yoo, K.Y, Lee, D.S., \& Franceschi, S. (2002). Hepatitis B and C virus prevalence in a rural area of South Korea: the role of acupuncture. Br J Cancer, Vol.87, No.3, pp. 314-318, ISSN 0007-0920

Simmons, R. (2006). Acupuncture with significant infection, in a 'well' patient. Acupunct Med, Vol.24, No.1, pp. 37, ISSN 0964-5284

Slater, P.E., Ben-Ishai, P., Leventhal, A., Zahger, D., Bashary, A, Moses, A., Costin, C., \& Shouval, D. (1988). An acupuncture-associated outbreak of hepatitis B in Jerusalem. Eur J Epidemiol, Vol.4, No.3, pp. 322-325, ISSN 0393-2990

Song, J.Y., Sohn, J.W., Jeong, H.W., Cheong, H.J., Kim, W.J., \& Kim, M.J. (2006). An outbreak of post-acupuncture cutaneous infection due to Mycobacterium abscessus. BMC Infect Dis, Vol.6, No.6, ISSN 1471-2334

Spleman, D.W., Weinmann, A., \& Spicer, W.J. (1993). Endocarditis following skin procedures. J Infect, Vol.26, No.2, pp. 185-189, ISSN 0163-4453

Stryker, W.S., Gunn, R.A., \& Francis, D.P. (1986). Outbreak of hepatitis B associated with acupuncture. J Fam Pract, Vol.22, No.2, pp. 155-158, ISSN 0094-3509 
Studd, R.C., \& Steward, P.J. (2004). Images in clinical medicine. Intraabdominal abscess after acupuncture. N Engl J Med, Vol.350, No.17, pp. 1763, ISSN 0028-4793

Sulaiman, H.A., Julitasari, Sie A., Rustam, M., Melani, W., Corwin, A., \& Jennings, G.B. (1995). Prevalence of hepatitis B and C viruses in healthy Indonesian blood donors. Trans $R$ Soc Trop Med Hyg, Vol.89, No.2, pp. 167-170, ISSN 0035-9203

Sun, C.A., Chen, H.C., Lu, C.F., You, S.L., Mau, Y.C., Ho, M.S., Lin, S.H., \& Chen, C.J. (1999). Transmission of hepatitis $C$ virus in Taiwan: prevalence and risk factors based on a nationwide survey. J Med Virol, Vol.59, No.3, pp. 290-296, ISSN 0146-6615

Tang, P., Walsh, S., Murray, C., Alterman, C., Varia, M., Broukhanski, G., Chedore, P., DeKoven, J., Assaad, D., Gold, W.L., Ghazarian, D., Finkelstein, M., Pritchard, M., Yaffe, B., Jamieson, F., Henry, B., \& Phillips, E. (2006). Outbreak of acupunctureassociated cutaneous Mycobacterium abscessus infections. J Cutan Med Surg, Vol.10, No.4, pp. 166-169, ISSN 1203-4754

Tien, C.H., Huang, G.S., Chang, C.C., Chang, D.M., \& Lai, J.H. (2008). Acupunctureassociated Listeria monocytogenes arthritis in a patient with rheumatoid arthritis. Joint Bone Spine, Vol.75, No. 4, pp. 502-503, ISSN 1297-319X

Uchino, K., Mochida, Y., Ebina, T., Tobe, M., Kobayashi, S., Yano, Y., Kobayashi, T., Nakazawa, I., Ishikawa, T., Kimura, K., Takanashi, Y., \& Umemura, S. (2002). Infected left atrial myxoma. Intern Med, Vol.41. No.11, pp. 957-960, ISSN 1444-0903

Vittecoq, D., Mettetal, J.F., Rouzioux, C., Bach, J.F., \& Bouchen, J.P. (1989). Acute HIV infection after acupuncture treatments. N Engl J Med, Vol.320, No.4, pp. 250-251, ISSN 0028-4793

Vucicevic, Z., Sharma, M., Miklic, S., \& Ferencic, Z. (2005). Multiloculated pleural empyema following acupuncture. Infection, Vol.33, No.4, pp. 297-298, ISSN 0300-8126

Walsh, B., Maguire, H., \& Carrington, D. (1999). Outbreak of hepatitis B in an acupuncture clinic. Commun Dis Public Health, Vol.2, No.2, pp. 137-140, ISSN 1462-1843

Warwick-Brown, N.P., \& Richards, A.E. (1986). Perichondritis of the ear following acupuncture. J Laryngol Otol, Vol.100, No.10, pp. 1177-1179, ISSN 0022-2151

Wiwanitkit, V. (2003). HIV infection after Chinese traditional acupuncture treatment. Complement Ther Med, Vol.11, No.4, pp. 272, ISSN 0965-2299

Woo, P.C., Li, J.H., Tang, W., \& Yuen, K. (2001). Acupuncture mycobacteriosis. N Engl J Med, Vol.345, No.11, pp. 842-843, ISSN 0028-4793

Woo, P.C., Leung, K.W., Wong, S.S., Chong, K.T., Cheung, E.Y., \& Yuen, K.Y. (2002). Relatively alcohol-resistant mycobacteria are emerging pathogens in patients receiving acupuncture treatment. J Clin Microbiol, Vol.40, No.4, pp. 1219-1224, ISSN 0095-1137

Woo, P.C., Lau, S.K., Wong, S.S., \& Yuen, K.Y. (2003). Staphylococcus aureus subcutaneous abscess complicating acupuncture: need for implementation of proper infection control guidelines. New Microbiol, Vol.26, No.2, pp. 169-174, ISSN 1121-7138

Woo, P.C., Lau, S.K., Teng, J.L., Tse, H., \& Yuen, K.Y. (2008). Then and now: use of $16 \mathrm{~S}$ rDNA gene sequencing for bacterial identification and discovery of novel bacteria in clinical microbiology laboratories. Clin Microbiol Infect, Vol.14, No.10, pp. 908934, ISSN 1198-743X

Woo, P.C., Lau, S.K., \& Yuen, K.Y. (2009). First report of methicillin-resistant Staphylococcus aureus septic arthritis complicating acupuncture: simple procedure resulting in 
most devastating outcome. Diagn Microbiol Infect Dis, Vol.63, No.1, pp. 92-95, ISSN 0732-8893

Woo, P.C., Lin, A.W., Lau, S.K., \& Yuen, K.Y. (2010). Acupuncture transmitted infections. BMJ, Vol.340, pp. 1151-1152, ISSN 0959-8138

Wu, C.T., Huang, J.L., Hsia, S.H., Lee, H.Y., \& Lin, J.J. (2009). Pott's puffy tumor after acupuncture therapy. Eur J Pediatr, Vol.168, No.9, pp. 1147-1149, ISSN 0340-6199

Yazawa, S., Ohi, T., Sugimoto, S., Satoh, S., \& Matsukura, S. (1998). Cervical spinal epidural abscess following acupuncture: successful treatment with antibiotics. Intern Med, Vol.37, No.2, pp. 161-165, ISSN 0918-2918 


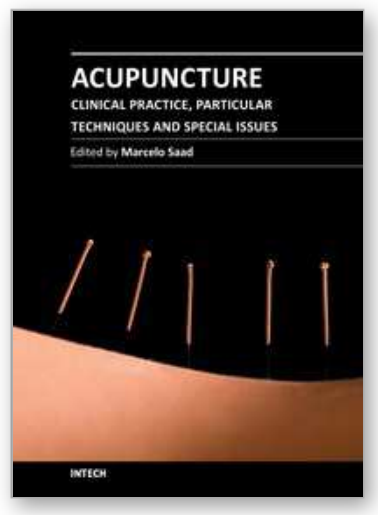

\author{
Acupuncture - Clinical Practice, Particular Techniques and Special \\ Issues \\ Edited by Prof. Marcelo Saad
}

ISBN 978-953-307-630-0

Hard cover, 138 pages

Publisher InTech

Published online 06, September, 2011

Published in print edition September, 2011

Acupuncture is growing in popularity world-wide. Acupuncture and related techniques are useful tools for treating a spectrum of diseases. However, there are still many areas of controversy connected to it due to the fact that mechanisms of action of acupuncture are not entirely clear. Another debilitating element is the absence of a convincing model of sham acupuncture for a control group in clinical trials. Therefore, there are still inappropriate prejudice and unfamiliarity regarding acupuncture. I hope this book can contribute to guide the advance of this ancient medical art. The reader will here find texts wrote by authors from different parts of the world. The chapters cover strategic areas to collaborate with the consolidation of the knowledge in acupuncture. The main objective is to share elements to make acupuncture more and better offered at health systems worldwide.

\title{
How to reference
}

In order to correctly reference this scholarly work, feel free to copy and paste the following:

Patrick CY Woo, Ada WC Lin and Susanna KP Lau (2011). Acupuncture Transmitted Infections, Acupuncture Clinical Practice, Particular Techniques and Special Issues, Prof. Marcelo Saad (Ed.), ISBN: 978-953-307-6300, InTech, Available from: http://www.intechopen.com/books/acupuncture-clinical-practice-particulartechniques-and-special-issues/acupuncture-transmitted-infections

\section{INTECH}

open science | open minds

\author{
InTech Europe \\ University Campus STeP Ri \\ Slavka Krautzeka 83/A \\ 51000 Rijeka, Croatia \\ Phone: +385 (51) 770447 \\ Fax: +385 (51) 686166 \\ www.intechopen.com
}

\author{
InTech China \\ Unit 405, Office Block, Hotel Equatorial Shanghai \\ No.65, Yan An Road (West), Shanghai, 200040, China \\ 中国上海市延安西路65号上海国际贵都大饭店办公楼 405 单元 \\ Phone: +86-21-62489820 \\ Fax: +86-21-62489821
}


(C) 2011 The Author(s). Licensee IntechOpen. This chapter is distributed under the terms of the Creative Commons Attribution-NonCommercialShareAlike-3.0 License, which permits use, distribution and reproduction for non-commercial purposes, provided the original is properly cited and derivative works building on this content are distributed under the same license. 